\title{
Samobójstwo i zachowania ryzykowne młodzieży. Analiza zjawisk w świetle założeń biopsychoekologicznych
}

\begin{abstract}
The above statement is of a well-known researcher of the subject of suicide. Suicide points to consider the phenomenon of various perspectives: philosophical, theological, sociological, clinical, psychological, and psycho-pedagogical. The choice of this direction of analysis depends on the theoretical and methodological assumptions adopted by the researcher. My study, focus on psycho-pedagogical. I will try to combine the phenomenon of suicide with the so-called "Young people with difficulties." My analysis will be carried out in the area of bio-psycho-ecological theory, which allows me to approach this subject in a multidimensional way, because I am of the opinion of multidimensional approach brings the best results.
\end{abstract}

Keywords: suicide, youth, difficulties, bioecological theory

\section{Wstęp}

Warto pamiętać, że ludzie nie zabijajq się dlatego, że nie chcq żyć. Raczej dlatego, że nie wiedzq, jak dalej żyć.

Brunon Hołyst

Dowyższe stwierdzenie znanego badacza problematyki samobójstw pozwala na rozpatrywanie tego zjawiska z różnych perspektyw: filozoficzno-teologicz- 
nej, socjologicznej, klinicznej, psychologicznej, i psychopedagogicznej. Wybór kierunku analizy zależy od przyjętych przez badacza założeń teoretycznych i metodologicznych. W moim opracowaniu uprzywilejowanym kierunkiem rozważań będzie ten ostatni, czyli psychopedagogiczny.

Spróbuję połączyć zjawisko samobójstwa z problematyką tzw. „młodzieży z trudnościami” (potocznie określanej „młodzieżą trudną”). Moja analiza przebiegać będzie przez obszar teorii biopsychoekologicznej, która pozwala mi na wielowymiarowe podejście do tej tematyki, gdyż uważam, iż taką ona właśnie jest.

\section{Samobójstwo wśród młodzieży}

Intensyfikujace się tempo życia oraz dokonujące się przemiany w sferze społeczno-kulturowej i obyczajowości powodują, że ludzie coraz częściej nie radzą sobie z trudnościami, które wynikają z tych przemian ${ }^{1}$. Na przestrzeni ostatnich lat coraz większą uwagę specjalistów wielu dziedzin, w tym psychologów wychowania, pedagogów i wychowawców, przykuwa zwiększająca się liczba młodych ludzi nieradzących sobie zarówno w procesie rozwoju osobistego, jak i socjalizacji. Rośnie liczba młodzieży porzucającej proces kształcenia, pozostającej na utrzymaniu rodziców, ulegającej uzależnieniom, zarówno tradycyjnym, jak i nowym, związanym z przestrzenią wirtualną. Powstają nowe kategorie młodzieży, np. NEET (Not in Education, Employment or Training) ${ }^{2}$. W tym kontekście spoglądam także na problematykę prób samobójczych i samobójstw u tzw. „młodzieży z trudnościami” .

Samobójstwa wśród młodzieży stanowią istotny problem w społeczeństwie globalnym, europejskim i polskim. Problem ten może być traktowany zarówno z perspektywy indywidualnego rozwoju, jak i płaszczyzny wspólnotowej, społecznej3 ${ }^{3}$ Możemy go studiować w świecie realnym (fizycznym), jak i w rzeczywistości wirtualnej ${ }^{4}$, która dla większości młodzieży jest światem realnym. Przypatrując się współczesnej diagnozie społecznej, dostrzegamy coraz większą dysproporcję pomiędzy światem potrzeb, pragnień, dążeń, oczekiwań jednostki a potrzebami, wartościami, normami, oczekiwaniami społeczeństwa. To napięcie, często kreowane poprzez propozycje zewnętrzne (nie zawsze pozytywne), doprowadza młodego człowieka do poszukiwania rozwiązań zaspokajających jego

${ }^{1}$ M. Stradomska, Zachowania suicydalne u dzieci i młodzieży a dobro młodzieży. Ujęcie integralne, „Fides et Ratio. Kwartalnik Naukowy” 1/37(2019), s. 421.

${ }^{2}$ Eurostat (2019), Statistics on young people neither in employment nor in education or training, https://ec.europa.eu/eurostat/statistics-explained/index.php/Statistics_on_young_people_neither_in_employment_nor_in_education_or_training [14.12.2019].

3 Z. Formella, Samobójstwo. Refleksja psychopedagogiczna, „Seminare” 20/2004, ss. 369-385.

${ }^{4}$ J.C. Franklin, X. Huang, D. Bastidas, Virtual reality suicide: Development of a translational approach for studying suicide causes, „Behaviour Research and Therapy” 120/2019. 
indywidualne potrzeby bycia, znaczenia, uznania, przynależności, komunikowania, w sposób natychmiastowy, często niekonwencjonalny, prowadzący do wyborów niekiedy kończących się tragicznie dla jego zdrowia czy życia 5 . W tym kontekście problematyka samobójstw, prób i myśli samobójczych powinna być rozpatrywana w perspektywie biopsychospołecznej ${ }^{6}$, będącej podejściem wielokierunkowym, wielopłaszczyznowym i dynamicznym, związanym zarówno z samą jednostką, jak i jej kontekstem rodzinnym, kulturowym, społecznym i środowiskowym, nie zapominając o istotnym czynniku wpływającym na człowieka, jakim jest kategoria upływającego czasu?

\subsection{Definicja i występowanie zjawiska samobójstwa}

Samobójstwa są drugą najczęstszą przyczyną śmierci młodych ludzi, a wskaźniki samobójstw stale rosną w ciągu ostatnich 10 lat ${ }^{8}$.

Samobójstwa należą do grupy zgonów spowodowanych przyczynami zewnętrznymi. Do tej grupy zgonów należą również wypadki komunikacyjne9 . Jednakże w ostatnich latach na całym świecie więcej ludzi popełnia samobójstwo, niż ginie w wyniku konfliktów wojennych czy w wypadkach komunikacyjnych.

Z informacji dostarczanych przez Światową Organizację Zdrowia możemy wydobyć kilka interesujących nas faktów na temat zjawiska samobójstw:

1. Samobójstwa stanowią drugą przyczynę zgonów w grupie wiekowej 15-29 lat.

2. Mężczyźni popełniają samobójstwa częściej niż kobiety.

3. Kobiety częściej podejmują próby samobójcze niż mężczyźni.

4. W krajach bogatszych najwięcej samobójców jest w grupie wiekowej 50 lat i więcej, natomiast w krajach rozwijających się przeważająca cześć samobójstw dotyczy młodszych gruph wiekowych ${ }^{10}$.

${ }^{5}$ B. Ziółkowska, J. Wycisk, Autodestruktywność dzieci i młodzieży, Dyfin, Warszawa 2019.

${ }^{6}$ R.W. Maris, Suicidology: A Comprehensive Biopsychosocial Perspective, Guilford Publications, New York 2019.

7 Z. Formella, Intervento psico-educativo alla luce della teoria bio-ecologica di Urie Bronfenbrenner, „Teologia i Moralność” vol. 14, 1(25)/2019, ss. 211-221.

${ }^{8}$ Centers for Disease Control and Prevention (CDC), 2017, Web-based Injury Statistics Query and Reporting System (WISQARS), https://www.cdc.gov/injury/ wisqars/index.html, dostęp 08/11/2019; World Health Organization (WHO), 2018, Suicide data, w: https://www.who.int/ mental_health/prevention/suicide/suicideprevent/en/ [8.11.2019].

${ }^{9}$ Eurostat (2016), Causes of death statistics, w: https://ec.europa.eu/eurostat/statistics-explained/index.php/Causes_of_death_statistics\#Developments_between_2006_and_2016 [8.11.2019].

${ }^{10}$ World Health Organization (2014), Preventing suicide: A global imperative. Executive summary, w: https://www.who.int/mental_health/suicide-prevention/exe_summary_english. pdf?ua=1 [8.11.2019]; A. Kielan, D. Olejniczak, Czynniki ryzyka oraz konswkwencje zachowan 
W Polsce samobójstwa stanowią siódmą przyczynę zgonów, zarówno wśród mężczyzn, jak i kobiet. W roku 2015 współczynnik zgonów spowodowanych samobójstwem wynosił w Polsce 14 na 100000 ludności (25 dla mężczyzn i 4 dla kobiet) ${ }^{11}$. Skala zjawiska samobójstw jest zależna od wieku, płci, miejsca zamieszkania, stanu cywilnego, wykształcenia, wyznawanej religii czy pozycji społecznej. Tendencje rozwojowe samobójstw w Polsce, opracowane na podstawie analizy samobójstw dokonanych w latach 1951-2012, prezentują wzrost ilościowy zjawiska w całej populacji, w tym szybki wzrost liczby samobójstw wśród mieszkańców wsi oraz zwiększony udział samobójstw u młodzieży i wśród kobiet ${ }^{12}$.

Badania statystyczne pokazują, iż w Polsce odsetek samobójstw dzieci i młodzieży utrzymuje się na niepokojąco wysokim poziomie. Zdaniem Andrzeja Zwolińskiego ${ }^{13}$ może to wynikać ze zjawiska odmładzania struktury samobójstw, co oznacza, iż coraz młodsze osoby (w tym również dzieci) decydują się na odebranie sobie życia ${ }^{14}$.

Poszukując definicji samobójstwa, można znaleźć wiele propozycji i interpretacji tego terminu. Wynika to z tego, że zjawisko samobójstwa jest zagadnieniem interdyscyplinarnym, którym zajmują się różne dziedziny nauki, oraz że zawiera w sobie trudny do określenia zbiór desygnatów (motywy, pragnienia, świadomość, intencje, uwarunkowania społeczno-kulturowe). Brzmienie definicji zależy od dziedziny, na potrzeby której została ona sformułowana ${ }^{15}$.

Irena Pospiszyl, reprezentujac interdyscyplinarny punkt widzenia, definiuje samobójstwo jako „świadome zachowanie jednostki, którego przynajmniej jednym z bezpośrednich celów jest pozbawienie siebie życia” ${ }^{16}$. Brunon Hołyst, znany i ceniony suicydolog, podkreśla, iż nie może być ono traktowane jako „zdarzenie jednorazowe, ahistoryczne, będące wynikiem zaburzenia równowagi życiowej. Jest ono finalnym elementem ciągu zaburzeń równowagi układów psychicznych

samobójczych z uwzględnieniem problematyki samobójstw dzieci i młodzieży, „Dziecko Krzywdzone. Teoria, badania, praktyka”3(17)/2018, ss. 10-11.

11 Główny Urząd Statystyczny, Atlas demograficzny Polski. Warszawa: Główny Urząd Statystyczny, 2017, https://stat.gov.pl/obszary-tematyczne/inne-opracowania/inne-opracowania-zbiorcze/atlas-demograficzny-polski,28,1.html [8.11.2019].

12 M. Jarosz, Samobójstwa w czasach kryzysu, w: Suicydologia, t. VII, ss. 5-15, Wydawnictwo Naukowe PWN, Warszawa 2015; A. Kielan, D. Olejniczak, Czynniki ryzyka...

${ }_{13}$ A. Zwoliński, Krzywdzone dzieci. Zagrożenia współczesnego dzieciństwa, WAM, Kraków 2012.

${ }^{14}$ K. Wasilewska-Ostrowska, Profilaktyka zachowań suicydalnych wśród młodzieży, „Dziecko Krzywdzone. Teoria, badania, praktyka” 3(14)/2015, s. 153.

15 A. Bąbik, D. Olejniczak, Uwarunkowania i profilaktyka samobójstw wśród dzieci i młodzieży w Polsce, „Dziecko Krzywdzone. Teoria, badania, praktyka” 13(2)/2014, ss. 99-121; A. Rainone i in., Il fenomeno del suicidio: epidemologia e definizioni, „Cognitivismo Clinico” 11(2)/2014, ss. 169-184; B. Goodfellow, K. Kölves, D. de Leo, Contemporary Definitions of Suicidal Behavior: A Systematic Literature Review, „Suicide and Life-Threatening Behavavior” 2(49)/2019, ss. 488-504.

${ }^{16}$ I. Pospiszyl, Patologie społeczne, Wydawnictwo Naukowe PWN, Warszawa 2009. 
i środowiskowych, jest konsekwencją »historii życia «”17. Podobnie jest ujmowane samobójstwo w kontekście teorii biopsychoekologicznej ${ }^{18}$.

Bardzo trudno jest podać jednoznaczną definicję samobójstwa w odniesieniu do młodzieży, bowiem akt samobójczy jest zwykle ostatecznością, a zatem zanim do niego dojdzie, młody człowiek wysyła swojemu otoczeniu różne sygnały, nie zawsze czyniąc to świadomie. Dla wielu osób z otoczenia młodego człowieka sygnały te są często nieczytelne czy niezrozumiałe ${ }^{19}$.

Współczesna suicydologia traktuje samobójstwo jako proces lub ciąg zdarzeń, w którym istotną rolę odgrywają myśli samobójcze. Myśli te rozpoczynają proces, który w sytuacji kryzysowej lub w innych niesprzyjających okolicznościach może skutkować próbą samobójczą lub doprowadzić do samobójczej śmierci ${ }^{20}$. Te stwierdzenia wydają mi się szczególnie ważne, kiedy mówimy o okresie dorastania i budowania własnej osobowości, zwłaszcza wśród młodzieży ze środowisk dysfunkcjonalnych, gdzie sytuacja kryzysowa jest permanentnie obecna i przeplata się z normalnym kryzysem dorastania. Niej jest więc łatwo odróżnić to zjawisko zarówno przez samego młodego człowieka, jak i przez osoby z jego otoczenia.

Jeżeli w tym kontekście weźmiemy pod uwagę wychowanków MOW-ów²1, czyli tzw. „młodzież z trudnościami”, to mamy tu do podkreślenia trzy istotne elementy, obecne w ich życiu:

- trudności psychospołeczne związane z procesem dorastania (ta charakterystyka jest wspólna całej populacji młodzieży);

- sytuacja kryzysowa, jaką jest decyzja o pobycie w MOW-ie;

- środowisko zwiększonego ryzyka, jakim jest przebywanie w MOW-ie.

17 B. Hołyst, Samobójstwo - przypadek czy konieczność, PWN, Warszawa 1983, s. 19.

${ }^{18}$ R.J. Cramer, N.D. Kapusta, A Social-Ecological Framework of Theory, Assessment, and Prevention of Suicide, „Frontiers in Psychology” 8/2017; P.N. Smith i in., Socio-ecological context and the interpersonal theory of suicide: A response to hjelmeland \& knizek, „Death Studies” 3/2019, ss. 1-5.

${ }^{19}$ W. Caan, Suicide in young people, „Journal of Public Mental Health” 1(18)/2019, ss. 46-48.

${ }^{20}$ K. Ostaszewski, Myśli samobójcze a sytuacja rodzinna oraz problemy inter- i eksternalizacyjne u młodzieży w wieku 14-16 lat, „Dziecko Krzywdzone. Teoria, badania, praktyka” 3(17)/2018, ss. 42-62.

${ }^{21}$ Młodzieżowe Ośrodki Wychowawcze (MOW) przeznaczone są dla dzieci i młodzieży niedostosowanych społecznie, wymagających stosowania specjalnej organizacji nauki, metod pracy i wychowania. Funkcjonują jako placówki resocjalizacyjno-wychowawcze, a dla dzieci i młodzieży z niepełnosprawnością intelektualną w stopniu lekkim jako resocjalizacyjno-rewalidacyjne. Do zadań MOW należy eliminowanie przyczyn i przejawów niedostosowania społecznego oraz przygotowanie wychowanków do życia zgodnego z obowiązującymi normami społecznymi i prawnymi. Młodzieżowe Ośrodki Wychowawcze przeznaczone są wyłącznie dla młodzieży, wobec której Wydziały Rodzinne i Nieletnich Sądów Rejonowych zastosowały (w trybie ustawy o postępowaniu w sprawach nieletnich) środek wychowawczy w postaci umieszczenia w MOW, https://www.ore.edu.pl/2015/04/mlodziezowe-osrodki-wychowawcze/ [29.12.2019]. 
Uważam, iż te elementy są bardzo istotne przy codziennej pracy wychowawczej z tzw. „młodzieżą z trudnościami”, a także z ich rówieśnikami przebywającymi poza MOW-em, ale przeżywającymi podobne trudności.

W większości publikacji samobójstwo jest traktowane jako droga, którą wybrała ofiara. Jest to wynik procesu decyzyjnego. Jeżeli ktoś podejmuje decyzję, to najczęściej uważa się, że jest świadomy możliwych konsekwencji danego działania. W przypadku samobójstw popełnianych przez dzieci i młodzież, ich pełna świadomość podejmowanego czynu budzi wątpliwości ze względu na brak doświadczenia życiowego oraz rozumienia tego, co tak naprawdę oznacza podjęcie decyzji o tak drastycznym zakończeniu problemów, które ofiary napotkały na początku swojego życia ${ }^{22}$. Często dzieci i dorastający młodzi ludzie nie zdają sobie sprawy, że samobójstwo to wybór między życiem a śmiercią. Traktują oni akt samobójstwa jako ucieczkę od swoich problemów, nie mając pomysłu na ich rozwiązanie ${ }^{23}$.

Niewątpliwie samobójstwo jest formą patologii społecznej i chociaż decyzja o nim jest podejmowana najczęściej indywidualnie, to jej skutki mają wymiar społeczny, a zatem rolą społeczeństwa jest także ochrona przed dokonywaniem samobójstw ${ }^{24}$.

\subsection{Przyczyny samobójstw młodzieży}

Samobójstwo generalnie jest skutkiem wspólnej interakcji czynników biologicznych, genetycznych, psychologicznych, socjologicznych, kulturowych i środowiskowych. Najczęściej któryś z nich dominuje lub wyraźnie przeważa nad pozostałymi.

Problemy, które mogą stać się przyczyną podjęcia decyzji o samobójstwie, w każdej grupie wiekowej są inne. Wydarzenia i sytuacje, które przez dorosłego nie byłyby traktowane jako problemy, dla młodych osób mogą wydawać się nie do rozwiązania. Zjawisko samobójstw u młodych ludzi trzeba analizować z uwzględnieniem uwarunkowań biologiczno-psychologicznych, które odgrywają szczególną rolę z uwagi na okres dorastania i związane z nim dodatkowe zagrożenia.

Światowa Organizacja Zdrowia ${ }^{25}$ wśród najczęściej występujących przyczyn samobójstw wśród dzieci i młodzieży wymienia: problemy rodzinne, rozstanie z przyjaciółmi lub sympatią, śmierć kogoś bliskiego, zerwanie związku uczu-

${ }^{22}$ B. Hołyst, Suicydologia, Lexis Nexis, Warszawa 2012.

${ }^{23}$ B. Hołyst, Samobójstwo - przypadek...; idem, 201, Samobójstwo - ucieczka przed światem czy wołanie o pomoc?, https://www.national-geographic.pl/aktualnosci/samobojstwo-ucieczkaprzed-swiatem-czy-wolanie-o-pomoc [30.12.2019].

${ }^{24}$ A. Bąbik, D. Olejniczak, Uwarunkowania i profilaktyka samobójstw...

25 Światowa Organizacja Zdrowia, Polskie Towarzystwo Suicydologiczne, Biuro Rzecznika Praw Dziecka, Ministerstwo Edukacji Narodowe, Zapobieganie samobójstwom - poradnik dla nauczycieli i innych pracowników szkoły, Fraszka Edukacyjna, Warszawa 2007. 
ciowego, konflikty z prawem, nacisk ze strony rówieśniczej, tyranizowanie, rozczarowanie wynikami w nauce, wysoki poziom wymagań w szkole, złą sytuację finansową rodziny, niechcianą ciążę, poważną chorobę somatyczną lub zakażenie chorobą przenoszoną drogą płciową.

Co do zasady, prawie nigdy nie zdarzają się pojedyncze przyczyny samobójstw. W literaturze przedmiotu czynniki suicydogenne (przyczyny) są najczęściej klasyfikowane w następujące kategorie ryzyka: demograficzne, społeczne, psychologiczne, kliniczne i biologiczne (zob. tab. 1).

Tabela 1. Kategorie czynników ryzyka popełnienia samobójstwa

\begin{tabular}{|c|c|}
\hline $\begin{array}{l}\text { Kategorie czynników } \\
\text { ryzyka popełnienia } \\
\text { samobójstwa }\end{array}$ & Czynniki ryzyka należące do poszczególnych kategorii \\
\hline 1. Demograficzne & $\begin{array}{l}\text { - płeć: męska, } \\
\text { - wiek: } 15-24 \text { lata } \\
\text { - miejsce zamieszkania: wieś. }\end{array}$ \\
\hline 2. Społeczne & $\begin{array}{l}\text { - } \text { sytuacja rodzinna: zaniedbanie/odrzucenie dziecka, konflikty } \\
\text { między rodzicami, rozwód; } \\
\text { - } \text { sytuacja szkolna: zmiany szkoły, trudności w przyswajaniu } \\
\text { wiedzy, konflikty z nauczycielami oraz rówieśnikami; } \\
\text { - trudna sytuacja materialna; } \\
\text { - przestępczość. }\end{array}$ \\
\hline 3. Psychologiczne & $\begin{array}{l}\text { - cechy osobowości, zmienny nastrój, agresja, impulsywność, } \\
\text { lęk - wydarzenia traumatyczne; } \\
\text { - brak umiejętności życiowych; } \\
\text { - uzależnienia behawioralne. }\end{array}$ \\
\hline 4. Chorobowe & $\begin{array}{l}\text { - psychiczne: depresja, psychoza maniakalno-depresyjna, schi- } \\
\text { zofrenia, zaburzenia osobowości typu borderline, alkoholizm; } \\
\text { - somatyczne: AIDS, choroby neurologiczne, pląsawica Hun- } \\
\text { tingtona, stwardnienie rozsiane oraz nowotwory. }\end{array}$ \\
\hline 5. Biologiczne & - neurochemiczne. \\
\hline
\end{tabular}

Źródło: opracowanie na podstawie A. Kielan, D. Olejniczak, Czynniki ryzyka oraz konsekwencje zachowan samobójczych z uwzględnieniem problematyki samobójstw dzieci i młodzieży, „Dziecko Krzywdzone. Teoria, badania, praktyka” 17(3)/2018.

Ad 1. Spośród czynników demograficznych warto podkreślić dane mówiące o tym, że dziewczęta podejmują próby samobójcze znacznie wcześniej niż chłopcy, a różnica ta jest obserwowana zwłaszcza pomiędzy 13. a 17. rokiem życia. Uważa się, że po 17. roku życia wskaźnik ten staje się wyższy u chłopców ${ }^{26}$.

${ }^{26}$ A. Rajewska-Rager, N. Lepczyńska, P. Sibilski, Czynniki ryzyka samobójstw u dzieci i młodzieży ze spektrum choroby i chorobq afektywnq dwubiegunowq o wczesnym poczq̨tku, „Psychiatria Polska” 49/3(2015), ss. 477-488. 
Ad 2. Wśród czynników społecznych na pierwszym miejscu jest wymieniana rodzina, a w niej trzy podstawowe przyczyny podnoszące ryzyko popełnienia samobójstwa:

- zbyt mało miłości,

- konflikty między rodzicami oraz

- zaborcza miłość ${ }^{27}$.

Jeśli chodzi o dziecko i nie tylko, to największy wpływ na jego zaburzony rozwój ma rozwód rodziców ${ }^{28}$. W przypadku środowiska szkolnego są tu wymieniane: częste konflikty z nauczycielami (bezosobowe relacje, wysokie wymagania lub ich brak, nadmierna dyscyplina) i rówieśnikami, zmiany szkoły, zagrożenie powtarzaniem klasy, trudności i brak osiągnięć w nauce, brak pomocy psychologiczno-pedagogicznej ${ }^{29}$.

Ad 3. Przy omawianiu psychologicznych czynników ryzyka samobójczego najczęściej podkreśla się niektóre cechy osobowości, zwłaszcza te charakteryzujące osobowość chwiejną emocjonalnie oraz z pogranicza borderline. Należy jednak być przy tym bardzo ostrożnym, mówiąc o okresie młodzieńczym, i potrafić rozróżnić pomiędzy kształtowaniem się osobowości w trakcie jej rozwoju a krystalizowaniem się pewnych cech osobowościowych, występujących często i przez dłuższy czas. Należą do nich: częsty zmienny nastrój, drażliwość, silna impulsywność, gwałtowność, podwyższona tendencja do reagowania lękiem, mała zdolność radzenia sobie ${ }^{30}$. Szczególną troską należy otoczyć młode osoby, które przeszły przez wydarzenia traumatyczne (różnego rodzaju przemoc, uzależnienia, śmierć rodzica zwłaszcza samobójcza, pobyt w więzieniu, choroby psychiczne lub terminalne, pobyt w domu dziecka, nabyta niepełnosprawność) ${ }^{31}$.

Także pozostałe dwa elementy, umieszczone w tabeli 2 (s. 86): umiejętności życiowe (braki zdolności do przystosowania i pozytywnego myślenia, które utrudniają jednostce skuteczne radzenie sobie z wyzwaniami codziennego życia: zdolność podejmowania decyzji, rozwiazywania problemów, krytycznego myślenia, kreatywnego i skutecznego komunikowania się, budowania zdrowych relacji z innymi, czyli social skills) ${ }^{32}$ i uzależnienia behawioralne (np. uzależnienie od

${ }^{27}$ E. Ringel, Gdy życie traci sens. Rozważania o samobójstwie, Wydawnictwo Glob, Szczecin 1987; A. Kielan, D. Olejniczak, Czynniki ryzyka..., ss. 9-26.

${ }^{28}$ J. Dzierżanowski, Psychospołeczna sytuacja dziecka w małżeństwach rozwodzących się, w: D. Krok, P. Landwójtowicz (red.), Rodzina w nurcie współczesnych przemian. Studia interdyscyplinarne, Opole 2010, ss. 255-278.

${ }^{29}$ A. Kielan, D. Olejniczak, Czynniki ryzyka...

${ }^{30}$ Ibidem.

${ }^{31}$ G.F. Mukhametzyanova i in., Psychological factors of suicidal risk among adolescents with speech disorders, „Opcion” 3-4(86)/2018, ss. 168-175.

32 J.H. Rathus, A. L. Miller, DBT (R) Skills Manual for Adolescents, Guilford Publications, New York 2015; M. Becciu, A. R. Colasanti (red.), In viaggio per crescere, Un manuale di auto-mutuo aiuto per gli adolescenti: per potenziare le proprie risorse e stare bene con sé e con gli altri, Franco Angeli, Milano 2016. 
papierosów, alkoholu, hazardu, Internetu, iphonu) ${ }^{33}$ należą do zjawisk szczególnie obecnych i przeżywanych wśród „młodzieży z trudnościami”.

Ad 4. Czynniki chorobowe wpływające na postawy samobójcze wymagają, ze względu na swoja specyfikę, odrębnego potraktowania. W moim opracowaniu podkreślę tylko jeden aspekt, a mianowicie związek samobójstwa z depresją. Należy sobie jasno zdawać sprawę z tego, iż depresja jest chorobą, a nie fanaberią zależną od naszej woli i może spotkać każdego bez względu na płeć, wiek, wykształcenie, status materialny czy społeczny.

Depresja jest zaburzeniem wchodzącym w skład zaburzeń afektywnych, czyli zaburzeń nastroju. Kiedyś uważano, iż tego typu zaburzenia nie dotyczą dzieci i młodzieży ze względu na niedojrzłość procesów psychicznych generujących depresję. Obecnie zaburzenia afektywne u dzieci i młodzieży rozpoznaje się na podstawie takich samych kryteriów diagnostycznych, jak w przypadku dorosłych, z pewnymi modyfikacjami.

Oto podstawowe czynniki odróżniające zaburzenia depresyjne od naturalnego obniżenia nastroju:

- długość trwania (zwykły smutek trwa przeciętnie od kilku godzin do kilku dni);

- towarzyszące inne objawy - spowolnienie psychoruchowe, utrata odczuwania przyjemności (anhedonia), problemy ze snem (bezsenność lub nadmierna senność), utrata lub wzmożony apetyt, współwystępowanie lęku i objawów somatycznych (np. bóle głowy, brzucha);

- brak reaktywności nastroju, czyli trudności w odwróceniu uwagi osoby chorej od swojego stanu i skierowaniu na inne sprawy (w przypadku dzieci objaw ten może nie występować);

- wpływ na codzienne funkcjonowanie (obowiązki są wykonywane z ogromnym trudem lub niewykonywane wcale);

- występujące myśli rezygnacyjne i/lub myśli samobójcze ${ }^{34}$.

Statystyki podają, że w okresie poprzedzającym dojrzewanie płciowe problem depresji rozpoznaje się u ok. 5 \% dzieci, z nieznaczną przewagą płci męskiej, a w okresie pokwitania - u 15-20\% (podobnie jak u dorosłych), z wyraźną przewagą płci żeńskiej ${ }^{35}$.

Ad 5. Czynniki biologiczne są jeszcze bardziej złożone. $\mathrm{Z}$ tego powodu nie będą one przedmiotem tego opracowania, gdyż wymagają osobnego potraktowania.

${ }^{33}$ A. Coutoumdjian, R. Baiocco, C. Del Miglio, Adolescenti e nuove dipendenze. Le basi teoriche, i fattori di rischio, la prevenzione, Editori Laterza, Roma 2011; C. Portelli, M. Papantuono Matteo, Le nuove dipendenze. Riconoscerle, capirle, superarle, San Paolo Edizioni, Cinisello Balsamo 2017.

${ }^{34}$ J. Chatizow, Depresja i samobójstwa dzieci i młodzieży. Żyć, nie umierać - poradnik dla rodzicow i nauczycieli, Difin, Warszawa 2018.

${ }^{35}$ Ibidem, ss. 15-16. 
W kontekście pracy z „młodzieżą z trudnościami” chcę zwrócić uwagę na jeszcze jeden interesujący czynnik związany z samobójstwami dzieci i młodzieży. Możnaby go nazwać czynnikiem transwersalnym, biorąc pod uwagę tabelę 1 (s. 79) z pięcioma kategoriami. Chodzi tutaj o zajwisko tzw. naśladownictwa.

Zjawisko to ma swoje źródła w silnym poczuciu przynależności do grupy lub przywiązania do jednostki, konformizmie i powtarzaniu tego, co robią inni ${ }^{36}$. W literaturze przedmiotu można się spotkać z określeniem samobójstwo zaraźliwe ${ }^{37}$. Pojawia się ono najczęściej w grupie rówieśników, gdy jeden z kolegów targnie się na swoje życie lub gdy w mediach pojawia się informacja o samobójczej śmierci młodej osoby. Motywy takich działań są różne: mówi się o poczuciu więzi między osobami w podobnym wieku (zwłaszcza dotyczy to osób w wieku dojrzewania), czasem zaś wynika to z poczucia winy, wstydu, że nie zapobiegło się śmierci przyjaciela. Może występować także tzw. efekt Wertera, polegający na tym, że jeśli jakaś znana osoba (aktor, piosenkarz, celebryta) targnie się na swoje życie, a media to nagłośnią, to fani mogą chcieć pójść w jego ślady i popełnić samobójstwo ${ }^{38}$.

\subsection{Próby i myšli samobójcze wšród młodzieży}

Próby samobójcze młodzieży swój początek mają w umyśle, gdzie najpierw pojawiają się jako myśli, idee, wyobrażenia, które potem zostają urealnione. Na częsttliwość pojawiających się czy też towarzyszących myśli samobójczych młodzieży przed podjęciem przez nich prób samobójczych wskazują dane zawarte na schematach 1 i 2.

Literatura przedmiotu podkreśla, iż najliczniejszą grupę stanowią młodzi, u których myśli samobójcze pojawiały się dopiero w sytuacji kryzysowej. Przypominam, że trzeba tu brać pod uwagę zarówno kryzys związany z okresem rozwojowym młodego czlowieka, jak i kryzysy sutuacyjne, krótko- lub długotrwałe, związane z konkretnymi wydarzeniami w jego życiu. Z pewnością badanie tzw. myśli samobójczych jest jednym z trudniejszych wyzwań badawczych. Należy przy tym zawsze pamiętać, iż nie mamy tu do czynienia tylko z liczbami (statystyką), ale z każdym konkretnym człowiekiem, z jego historią, oryginalnością i niepowtarzalnością 39 .

${ }^{36}$ E. Cattelino (red.), Rischi in adolescenza. Comportamenti problematici e disturbi emotivi, Carocci, Roma 2010; A. Zwoliński, Krzywdzone dzieci...; M.J. Kral, The Idea of Suicide. Contagion, Imitation, and Cultural Diffusion, Routledge, New York 2019.

37 A. Czabański, Charakterystyka zachowań samobójczych młodzieży, w: Samobójstwa wśród młodzieży - wołanie o pomoc. Materiały z Międzynarodowej Konferencji Naukowej z 22.01.2010 (ss. 5-16), Wydawnictwo Szkoły Wyższej im. Bogdana Jańskiego. Wydział Zamiejscowy w Chełmie, Chełm 2010.

${ }^{38}$ I. Pospiszyl, Patologie społeczne, Wydawnictwo Naukowe PWN, Warszawa 2009; K. Wasilewska-Ostrowska, Profilaktyka zachowań...

${ }^{39}$ L. Hayes, A. Bailey, J. Ciarrochi, W pułapce myśli - dla nastolatków. Jak skutecznie poradzić sobie z depresja, stresem i lękiem, Gdańskie Wydawnictwo Psychologiczne, Sopot 2019. 


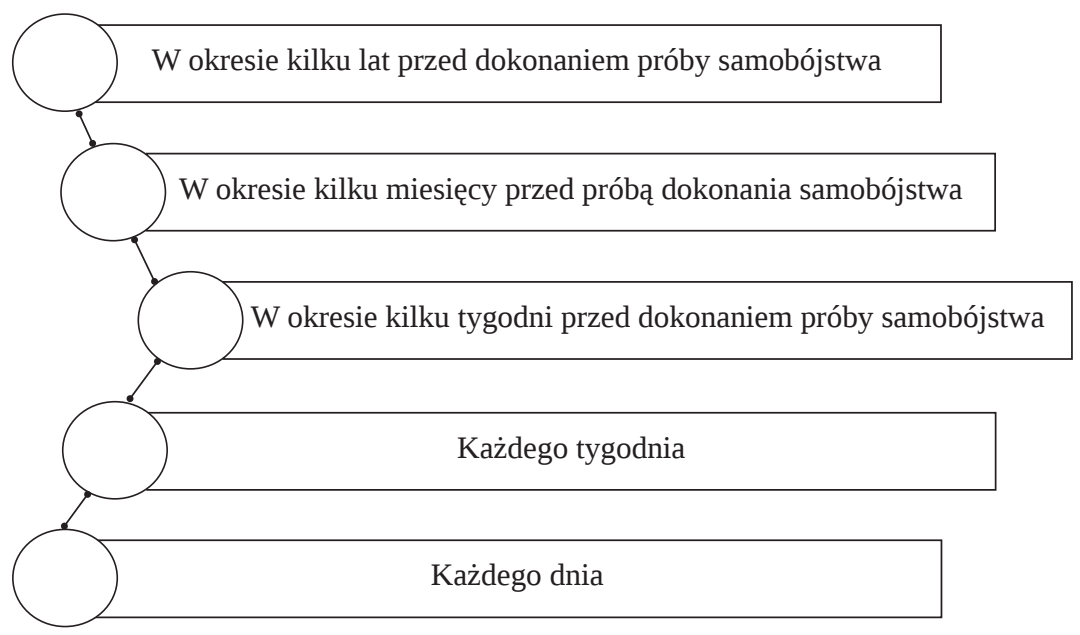

Schemat 1. Jak często przed podjęciem próby samobójczej towarzyszyły Ci myśli samobójcze?

Źródło: opracowano na podstawie: M. Makara-Studzińska, Przyczyny prób samobójczych u młodzieży w wieku 14-18 lat, „Psychiatria” 10(2)/2013; K. Ostaszewski, Myśli samobójcze a sytuacja rodzinna oraz problemy inter- i eksternalizacyjne u młodzieży w wieku 14-16 lat, „Dziecko Krzywdzone. Teoria, badania, praktyka” 17(3)/2018.

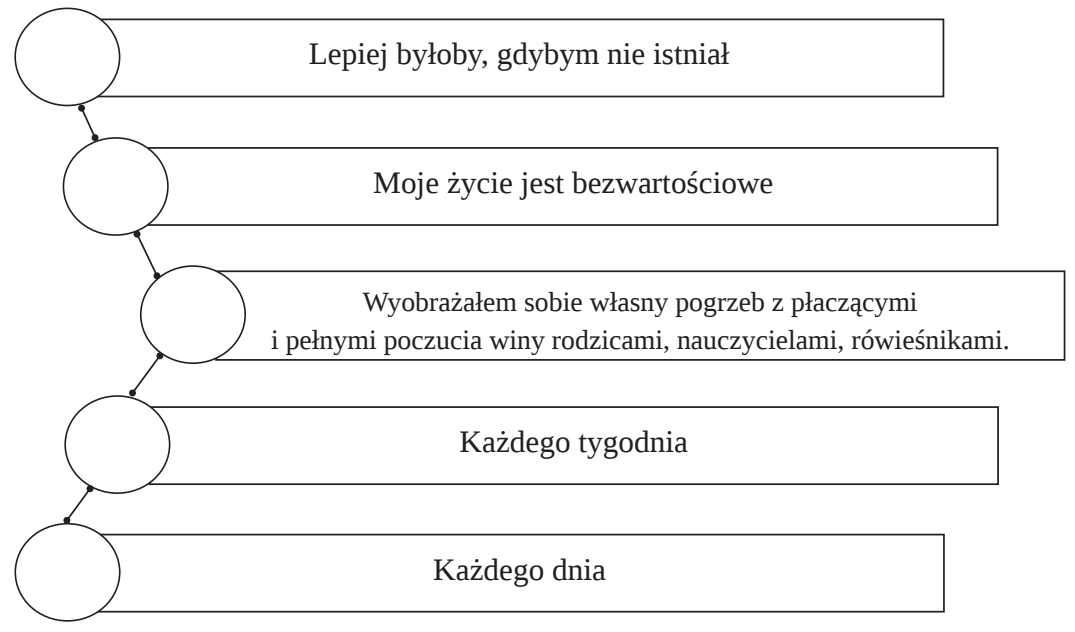

Schemat 2. Określ treść Twoich myśli samobójczych

Źródło: opracowano na podstawie: M. Makara-Studzińska, Przyczyny prób samobójczych...; K. Ostaszewski, Myśli samobójcze... 
Jeszcze trudniejsza staje się ocena liczby prób samobójczych (suicidal attempts) w populacji młodzieży, gdyż liczba osób trafiających z tego powodu pod opiekę lekarską czy psychologiczną stanowi tylko część spośród tych, którzy usiłowali odebrać sobie życie. Podkreśla się, że w wieku rozwojowym częstsze jest występowanie myśli samobójczych i wyobrażeń samobójczych (suicidal ideation) w porównaniu z osobami dorosłymi, natomiast osoby dorosłe częściej podejmują próby samobójcze kończące się zgonem ${ }^{40}$.

Szacuje się, że 70-90\% młodych osób, które miały myśli suicydalne lub podejmowały próby samobójcze, miały zdiagnozowane zaburzenia lub chorobę psychiczną, wśród których dominowały: zaburzenia nastroju (zaburzenia depresyjne, choroba afektywna dwubiegunowa), zaburzenia lękowe, nadużywanie substancji psychoaktywnych oraz zaburzenia zachowania. Istotnym czynnikiem ryzyka są również współistniejące choroby somatyczne, a zwłaszcza te o przewlekłym przebiegu ${ }^{41}$.

W badaniach wykazano, że myśli samobójcze i samo samobójstwo często związane są z depresją młodzieńczą, która wpisana jest w wiek dojrzewania ${ }^{42}$. Wydaje się, że w naszej kulturze europejskiej ten rodzaj zagrożenia sprawia dzisiaj młodzieży sporo problemów.

Depresja młodzieńcza jest tu określana jako ponadprzeciętny kryzys okresu dorastania. W tym okresie trzeba ukształtowć własną tożsamość seksualną (co jest przecież niezwykle trudne, padają pytania o to, jaki będę, czy będę się podobał płci przeciwnej, czy mi się powiedzie w życiu seksualnym), własny system wartości, własną tożsamość w odniesieniu do tego, kim będę w przyszłości. Jest to okres bardzo trudny dla młodego człowieka. Poza tym jest to czas naturalnej i stopniowej separacji od rodziców. I to wszystko razem stwarza duże zagrożenia dla młodzieży, zwłaszcza w wieku 14-19 lat ${ }^{43}$.

Podsumowujac wyniki dotyczące rozpowszechnienia myśli samobójczych oraz rozpowszechnienia problemów inter- i eksternalizacyjnych, znawcy problematyki sugerują, że u 20-25\% nastolatków we wczesnym okresie dojrzewania występują problemy dotyczące zdrowia psychicznego, które wymagają pomocy ze strony dorosłych lub specjalistów. Ponadto wyniki badań potwierdzają związek sytuacji rodzinnej z kondycją psychiczną nastolatków, dlatego tak ważna jest współpraca w profilaktyce samobójstw oraz rozwiązywaniu innych problemów zdrowia psychicznego młodych ludzi ${ }^{44}$.

\footnotetext{
${ }^{40}$ K. Ostaszewski, Myśli samobójcze...

${ }^{41}$ A. Rajewska-Rager, N. Lepczyńska, P. Sibilski, Czynniki ryzyka samobójst...

${ }^{42}$ L. Hayes, A. Bailey, J. Ciarrochi, $W$ pułapce myśli...

${ }^{43}$ K. Wasilewska-Ostrowska, Profilaktyka zachowań..

${ }^{44}$ K. Ostaszewski, Myśli samobójcze...
} 


\section{Zachowania ryzykowne u „młodzieży z trudnościami”}

Trudności życiowe są wpisane w prawa rozwojowe każdego człowieka ${ }^{45}$. Jest rzeczą niemożliwą podanie jednego określenia trudności, ich jednoznacznego zdefiniowania. Z jednej strony są one swoistym wyzwaniem, któremu trzeba stawić umiejętnie czoła, najlepiej w odpowiednim środowisku. Z drugiej strony są one zagrożeniem, przed którym nie da się uciec czy schować, trzeba podjąć to wyzwanie. Tabela 2 przedstawia podstawowe czynniki ryzyka, które mogą być jednocześnie symptomami samobójstwa wśród młodzieży.

\subsection{Pojęcie zachowania ryzykownego}

Zacznijmy od pytania: „Czy można wychowywać bez ryzyka?” Odpowiedz brzmi: Nie!

Każde działanie wychowawcze prowadzące do zmiany zawiera w swej naturze ryzyko. Problemem nie jest ryzyko samo w sobie, ale wszystko to, co mu towarzyszy. Możemy tu mówić o tzw. ryzyku wychowawczym dozwolonym i niedozwolonym (zob. schemat 3).

Obok pojęcia ryzyka wychowawczego często jest używane również pojęcie zaburzenia zachowania. To drugie zjawisko jest najczęściej konsekwencją źle zarządzanego ryzyka wychowawczego.

Zaburzenia zachowania zdefiniowane zostały jako „zespół zaburzeń charakteryzujących się brakiem samokontroli, nadmierną aktywnością, nieuwagą, agresją, zapędami destrukcyjnymi i buntem"46.

Brunon Hołyst podkreśla, iż są to zaburzenia charakteryzujące się nadmiernym nasileniem emocji, związane są z występowaniem silnych, negatywnych emocji, które trwają długo oraz pojawiają się dość często - warto zaznaczyć, że samobójstwo jest procesem, zatem osoba przechodzi pewien proces, który może zostać zakończony samobójstwem ${ }^{47}$. Można tu wymienić trzy aspekty emocji, które mogą odróżniać zaburzenie od normy. Są to: intensywność, czas trwania, a także częstotliwość występowania. Występowanie określonych emocji związane jest z pojawianiem się trudności w funkcjonowaniu, w tym zachowań autodestrukcyjnych - można tu wyróżnić działania mające na celu akty suicydalne ${ }^{48}$.

${ }^{45}$ L. Hayes, J. Ciarrochi, Trudny czas dojrzewania. Jak pomóc nastolatkom radzić sobie z emocjami, osiq̨gać cele i budować więzi, stosujq̨c terapię akceptacji i zaangażowania oraz psychologię pozytywna, Gdańskie Wydawnictwo Psychologiczne, Sopot 2019.

${ }^{46}$ M. Stradomska, Zachowania suicydalne..., s. 422.

47 B. Hołyst, Suicydologia, Lexis Nexis, Warszawa 2012.

${ }^{48}$ M. Stradomska, Zachowania suicydalne... 


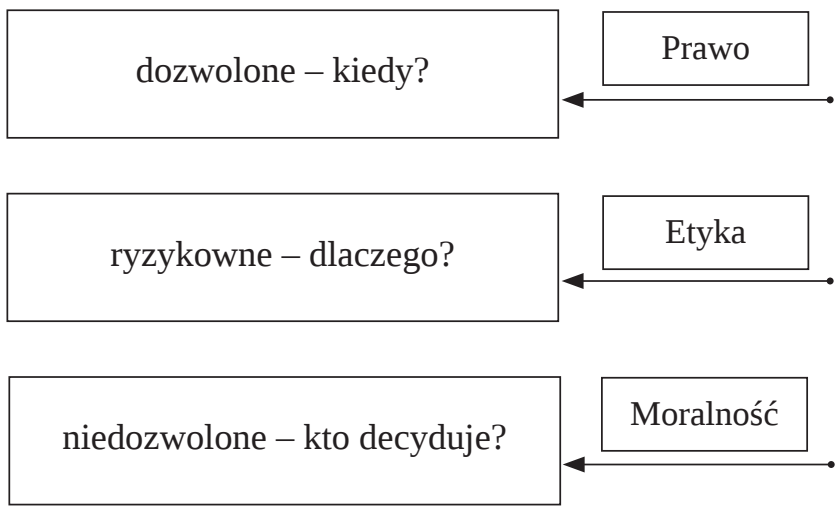

Schemat 3. Rodzaj zachowania w obszarze wychowania Źródło: opracowanie własne.

\subsection{Koncepcja tzw. „młodzieży z trudnościami”}

Dotyczy to przede wszystkim kategorii „młodzieży z trudnościami” osobistymi, związanymi często z samym procesem dorastania, z niełatwymi relacjami rodzinnymi, szkolnymi, rówieśniczymi oraz emocjonalnymi. Generalnie nie mówimy tu o młodzieży, która ma zdiagnozowane zaburzenia według standardowych procedur. Ta kategoria młodzieży podlega innej procedurze terapeutycznej, a więc i specjalnego podejścia psychopedagogicznego w wychowaniu ${ }^{49}$.

Jeżeli te trudności osobiste napotykają niesprzyjające warunki środowiskowe, zwłaszcza rodzinne, do których często dołączają się te szkolne czy rówieśnicze, to młodzież ta napotyka ogromne trudności w realizowaniu siebie czy odpowiadaniu na propozycje zachowania ze strony społecznej (etyka, systemy wartości, moralność itp.).

W tym sensie określam tę kategorię młodych ludzi „młodzieżą z trudnościami”, a nie „młodzieżą trudną”. Chce podkreślić w ten sposób, iż najczęściej przyczyny tych ich trudności tkwią w środowisku młodzieży, a rzadziej w niej samej. Tak naprawdę niewielka jest grupa tzw. „młodzieży trudnej”, gdzie można zdiagnozować dewiacje osobowościowe, wymagające specjalnego traktowania. Znacznie większa jest grupa młodzieży przeżywającej rożnego rodzaju trudności dorastania,

49 Z. Formella, Psicologia dell'Intervento educativo, LAS, Roma 2015. 


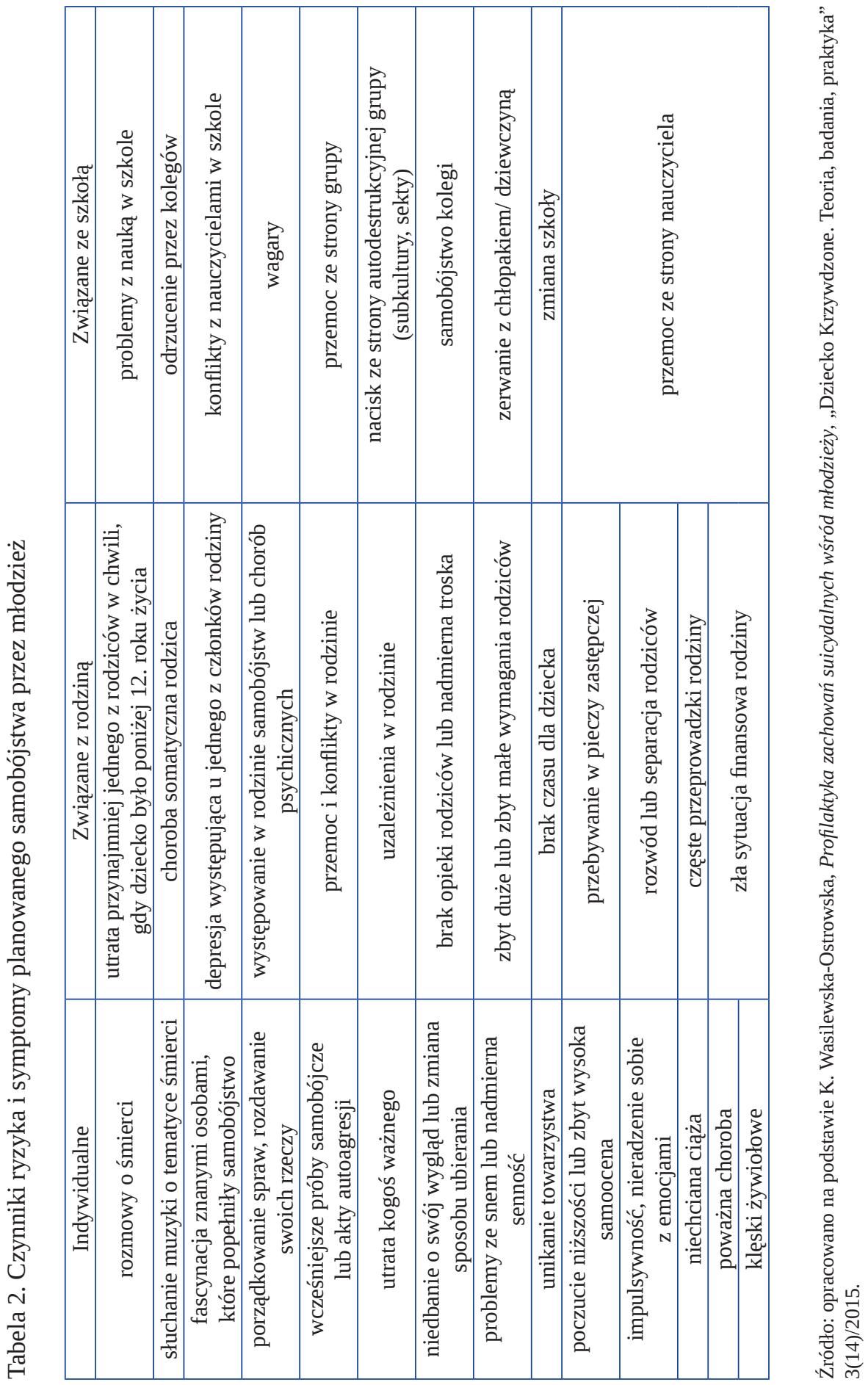


które w przeważajacym stopniu mogą i powinny być rozwiązywane na drodze „normalnej” interwencji wychowawczej ${ }^{50}$.

Zdecydowana większość młodych ludzi „nabywa” trudności poprzez swoje relacje ze światem zewnętrznym, czyli są one wynikiem interakcji pomiędzy osobą a jej środowiskiem wzrastania. Można to obrazowo przedstawić podkreślając, iż trudności (objawiające się w zachowaniu) najpierw niejako „wchodzą, przenikają” do młodzieży, następnie „przekształcają się” w jej wnętrzu, a potem dopiero z niej „wychodzą”. Trudności zachowania są więc zdecydowanie nabyte, rzadziej „wrodzone”.

I tu jako przykład może posłużyć młodzież z MOW-ów. Oczywiście mamy wśród tych wychowanków takich z zaburzeniami osobowości. Jest to jednak raczej wynik złej diagnozy lub nie do końca funkcjonującego systemu procedur czy samej resocjalizacji. Przeważająca większość wychowanków MOW-wów to „młodzież z trudnościami” - czyli ta, która manifestuje trudności wychowawcze, relacji, adaptacji społecznej itp. Są one najczęściej wynikiem rozwoju i wzrastania tej młodzieży w środowisku dysfunkcjonalnym, tzn. niezabezpieczającym prawidłowego funkcjonowania indywidualnego i społecznego. W tym też kontekście jak najbardziej uzasadnione jest mówienie o szeroko pojętej prewencji w działaniach państwowych, społecznych i środowiskowych, a dopiero potem o resocjalizacji, jako konieczności będącej wynikiem słabego funkcjonowania tych pierwszych czynników ${ }^{51}$.

Wzajemne relacje pomiędzy czynnikami osobowościowymi a środowiskowymi przedstawia schemat 4 . W tym kontekście możemy mówić o interwencji prewencyjnej lub rekonstrukcyjnej.

Jeżeli w potocznym języku używamy wyrażenia „to jest człowiek z trudnym charakterem”, to w jaki sposób należy to rozumieć? Urodził się już taki (a więc nic nie można zrobić?) czy „uczyniono go takim” (a więc można to zmienić?).

Moim zdaniem charakter jest przede wszystkim (w przeciwieństwie do temperamentu) ukształtowany w czasie rozwoju osobistego przy dużym wpływie czynnikow zewnętrznych. Potocznie można by to zwrzeć w znanym powiedzeniu: „kto z kim przestaje, takim się staje”. Nie zgadzam się oczywiście z teorią predystynacji, ale uznaję fakt dużego wpływu środowiska na rozwój osobisty, zwłaszcza w okresie dziecięcym i młodzieńczym² .

50 Z. Formella, Intervento psico-educativo...

51 Najwyższa Izba Kontroli, 2018 Działalność resocjalizacyjna młodzieżowych ośrodków wychowawczych. Informacja o wynikach kontroli. LSZ.410.004.00.2017. Nr ewid. 153/2017/P/17/099/ LSZ, https://www.nik.gov.pl/aktualnosci/nik-o-resocjalizacji-w-mlodziezowych-osrodkachwychowawczych.html [30.12.2019].

52 Z. Formella, A. Ricci, Bambini facili o difficili? Dal carattere all'educazione familiare da o a 6 anni, Anicia, Roma 2013; D. Grządziel, Educare il carattere. Per una pratica educativa teoricamente fondata, LAS, Roma 2014. 


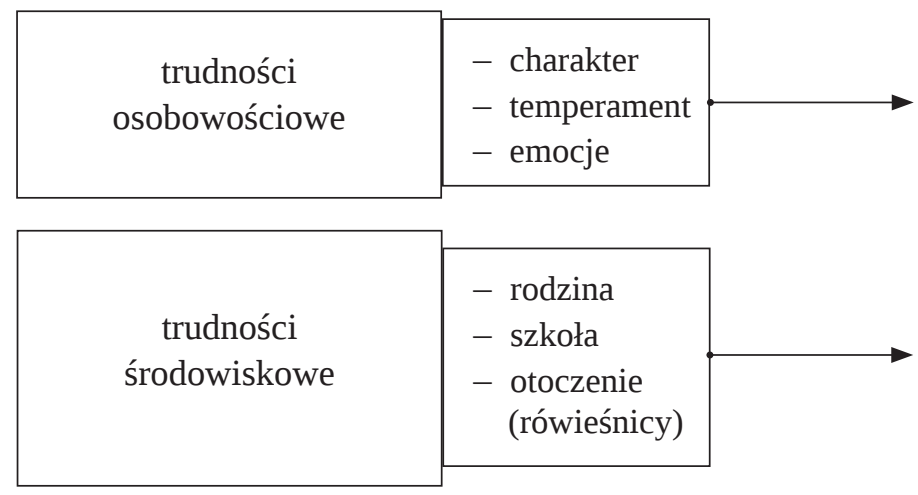

Schemat 4. Relacje pomiędzy trudnościami wychowawczymi „nabytymi” a „wrodzonymi”

Źródło: opracowanie własne.

\section{Interwencja biopsychoekologiczna wobec zagrożeń suicydalnych młodzieży MOW-u}

Każda interwencja ma na celu zmianę. W wypadku interwencji wychowawczej, psychowychowawczej, chodzi zawsze o zmianę w kierunku na lepsze ${ }^{53}$. Fakt ten nie podlega dyskusji. Problemem natomiast jest określenie, czy jest to lepsze? Lepsze dla kogo? Dla człowieka czy dla instytucji? To jest chyba jeden z najtrudniejszych dylematów w praktyce, zwłaszcza wychowawczej. Kłania nam się tu odwieczne pytanie - mające także odzwierciedlenie w Ewangelii - „prawo jest dla człowieka czy człowiek jest dla prawa?” (por. Mk 2,23-3,6). Wychowanek jest dla Instytucji (przedstawiciela Prawa) czy Instytucja jest dla wychowanka? Niby proste pytanie i dla większości pewnie i prosta odpowiedź, ale w praktyce okazuje się to bardzo skomplikowane. Innymi słowy, powracamy do naszego pytania o relacje pomiędzy człowiekiem a jego środowiskiem. Kto jest dla kogo? I w jaki sposób?

Jedynie nieudane próby samobójcze można rozpatrywać w kategoriach skutków dla danej osoby. Jeżeli w wyniku podjętego zamachu samobójczego nastąpił zgon samobójcy, wtedy konsekwencje jego zachowania będą ponosili członkowie jego rodziny i osoby z najbliższego otoczenia ${ }^{54}$. Konsekwencje zachowań samobójczych

53 Z. Formella, Intervento psico-educativo...

54 B. Hołyst, Suicydologia, Lexis Nexis, Warszawa 2012. 


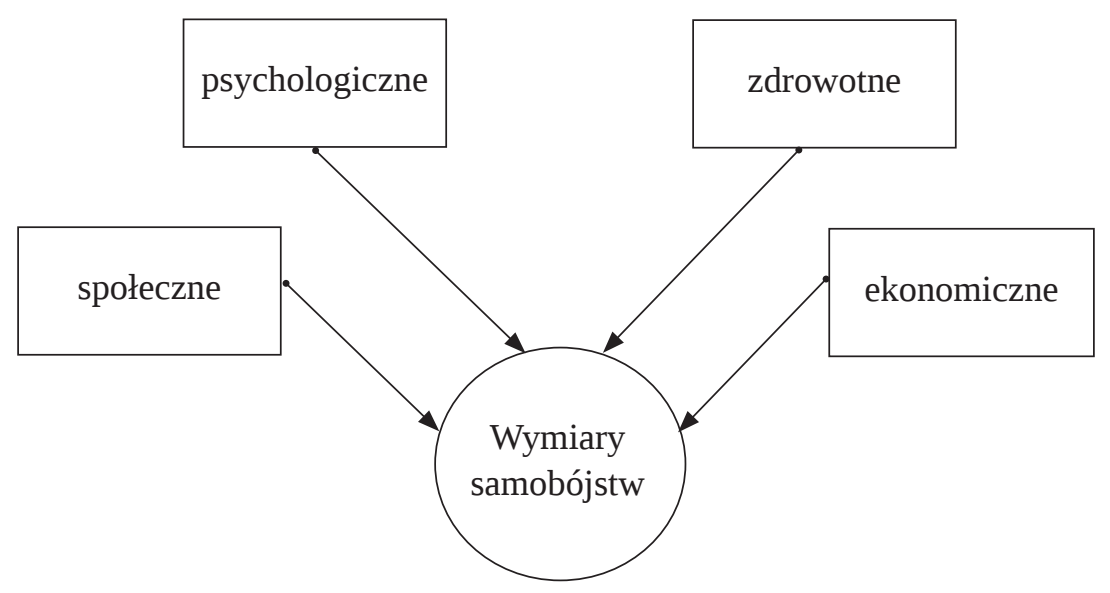

Schemat 5. Obszary skutków zachowań autodestrukcyjnych Źródło: opracowanie na podstawie A. Kielan, D. Olejniczak, Czynniki ryzyka...

mają zarówno jednostkowy, jak i społeczny charakter. Schemat 5 przedstawia cztery wymiary skutków zachowań autodestrukcyjnych.

Próba samobójcza może być próbą sił, wymuszeniem pewnych decyzji lub chęcią zwrócenia na siebie uwagi. Jest to szczególnie istotne w przypadku młodzieży. Nie zawsze bowiem młoda osoba, która próbuje popełnić samobójstwo, rzeczywiście chce to zrobić. Ci natomiast, którzy mają taki zamiar, często „wołają” wcześniej o pomoc, czekają, aż ktoś zauważy ich problem. Samobójstwo bowiem to pewien proces. Dobrze zobrazował to Ringel w swoich założeniach zespołu presuicydalnego. Wyróżnił on trzy etapy: zawężenie (koncentracja na własnych problemach, które wydają się niemożliwe do rozwiązania, towarzyszy temu zamknięcie w sobie oraz izolacja społeczna), hamowanie agresji (w tej fazie człowiek nie wyładowuje swoich emocji na zewnątrz, tylko je kumuluje, aż w końcu pojawia się autoagresja), wyobrażenie śmierci (pierwsze myśli o samobójstwie). Ważna jest też koncepcja zachowań suicydalnych Brunona Hołysta, który zalicza do nich „samobójstwo wyobrażone” (nawracające myśli o samobójstwie), „samobójstwo upragnione” (przygotowywanie się do samobójstwa, poszukiwanie informacji w Internecie, kupowanie potrzebnych przedmiotów, np. leków), „samobójstwo usiłowane” (próba samobójcza), „samobójstwo dokonane” (samobójstwo zakończone śmiercią). W przypadku nastolatków wyróżnia się natomiast samobójstwa prawdziwe - których celem jest śmierć, rzekome - ich intencją nie jest śmierć, 


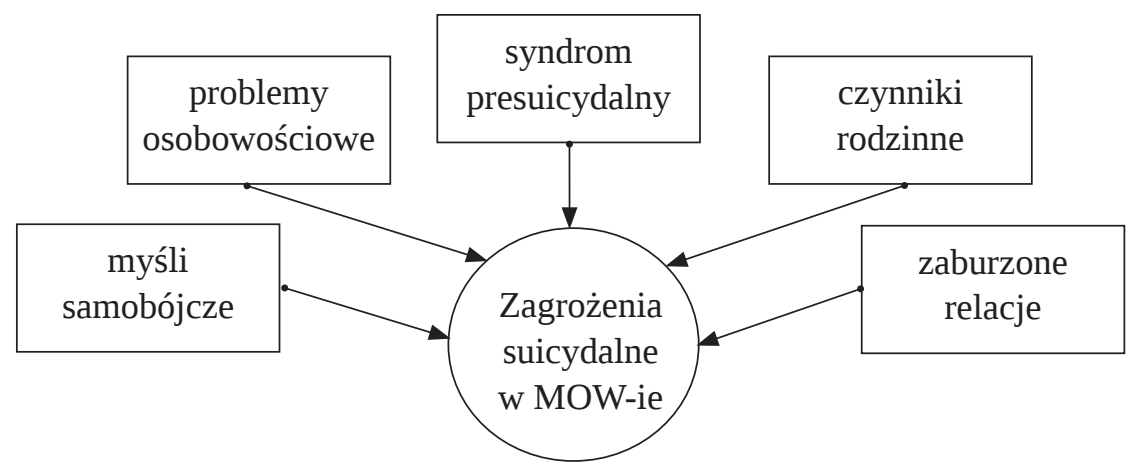

Schemat 6. Zagrożenia suicydalne w MOW-ie

Źródło: opracowanie własne.

a wywołanie w otoczeniu poczucia winy, wstydu, może to też być akt zemsty lub rozpaczy, oraz demonstratywne - których istotą jest zwrócenie uwagi bliskich na problemy i potrzeby osoby, która podejmuje próbę samobójczą ${ }^{55}$. Interwencja jest tu zawsze dostosowana do rodzaju proby samobójczej, oczywiście jeżeli uda się wcześniej ją adekwatnie zdiagnozować.

Schemat 6 pomaga nam spojrzeć na te problematykę w środowisku MOW-u.

Propozycja pięciu podstawowych czynników zagrożenia suicydalnego w środowisku MOW-u ukierunkowuje nasze działania interwencyjne, zarówno te bezpośrednie, jak i te o charakterze prewencyjnym. Jak do nich podejść w praktyce? Oto niektóre wskazania:

- syndrom presuicydalny - umiejętność odczytywania sygnałów;

- czynniki rodzinne - znajomość procesu i skutków dysfunkcjonalności rodziny, umiejętność towarzyszenia w procesie dążenia do zakładania własnej rodziny;

- zaburzone relacje - umiejętność ich odczytania i wspomagania w nabyciu zdolności do ich autoregulacji w odniesieniu do samego siebie i własnego środowiska (rodzinnego, szkolnego, kulturowo-religijnego, społecznego);

- problemy osobowościowe - poznawanie i akceptacja cech własnej osobowości; umiejętności radzenia sobie z sobą samym; konfrontacja z pozytywnymi wzorami;

- myśli samobójcze - pozytywne przykłady wyjścia z sytuacji trudnych; spotkania z osobami i ich pozytywne świadectwa (imitacja, naśladowania); pozytywne środowisko wsparcia.

${ }^{55}$ K. Wasilewska-Ostrowska, Profilaktyka zachowań... 


\section{Zakończenie}

Interwencja wychowawcza czy też psychowychowawcza to przede wszystkim chęć pomocy drugiemu człowiekowi. Chcieć pomoc to również móc pomóc, ale pod warunkiem, że się wie dlaczego i jak pomóc. Zakończę moje opracowanie zasłyszanym, stymulującym opowiadaniem na temat interwencji.

Pewien pracowity rolnik odpoczywajq̨c w południe pod drzewem, spostrzegł zwisajq̨cy z jego gałęzi kokon motyla. Kokon ten był prawie całkowicie zamknięty, z wyjątkiem malutkiego otworu. Rolnik, zaciekawiony, zagląda przez tę niewielkq szparkę i widzi małego motyla, który usiłuje rozprostować skrzydła, używając przy tym całej swojej siły. Motyl usiłuje wydostać się z kokonu, ale jego poczynania przynoszq znikome wyniki.

Rolnik wyjmuje z kieszeni scyzoryk i delikatnie poszerza nim otwór w kokonie, tak aby motyl mógł się z niego wydostać bez większego wysiłku. W tym momencie zachodzi coś niespodziewanego: motyl, któremu udzielono pomocy, aby wyszedł z kokonu wcześniej niż to było przewidziane, nie majq̨c jeszcze wystarczajq̨co wyrobionych mięśni, aby móc samodzielnie fruwać, spada bezsilnie na ziemię...

Rolnik zrozumiał, iż popełnił duży błąd i wyciqgnął z tej otrzymanej lekcji wnioski, których nie zapomni do końca swojego życia: „poprzez trudności natura czyni cię mocniejszym i przygotowuje cię do realizowania twoich marzeń w przyszłości”.

Interwencja zatem polega na tym, by przede wszystkim nie pogarszać, a następnie szanować prawa natury i dopiero na końcu czynić to, co możliwe.

\section{Literatura}

Bąbik A., Olejniczak D., Uwarunkowania i profilaktyka samobójstw wśród dzieci i młodzieży w Polsce, „Dziecko Krzywdzone. Teoria, badania, praktyka” 13(2)/2014.

Becciu M., Colasanti A.R. (red.), In viaggio per crescere, Un manuale di auto-mutuo aiuto per gli adolescenti: per potenziare le proprie risorse e stare bene con sé e con gli altri, Franco Angeli, Milano 2016.

Caan W., Suicide in young people, ,Journal of Public Mental Health” 18(1)/2019.

Cattelino E. (red.), Rischi in adolescenza. Comportamenti problematici e disturbi emotivi, Carocci, Roma 2010.

Centers for Disease Control and Prevention (CDC), Web-based Injury Statistics Query and Reporting System (WISQARS), 2017, https://www.cdc.gov/injury/wisqars/index. html [8.11.2019].

Chatizow J., Depresja i samobójstwa dzieci i młodzieży. Żyć, nie umierać - poradnik dla rodzicow i nauczycieli, Difin, Warszawa 2018.

Coutoumdjian A., Roberto B., Del Miglio C., Adolescenti e nuove dipendenze. Le basi teoriche, i fattori di rischio, la prevenzione, Editori Laterza, Roma 2011.

Cramer J.R., Kapusta D., A Social-Ecological Framework of Theory, Assessment, and Prevention of Suicide, „Frontiers in Psychology” 8/2017. 
Czabański A., Charakterystyka zachowań samobójczych młodzieży. W: Samobójstwa wśród młodzieży - wolanie o pomoc. Materiały z Międzynarodowej Konferencji Naukowej z 22.01.2010, Wydawnictwo Szkoły Wyższej im. Bogdana Jańskiego. Wydział Zamiejscowy w Chełmie, Chełm 2010.

Dzierżanowski J., Psychospołeczna sytuacja dziecka w małżeństwach rozwodzqcych się, w: D. Krok, P. Landwójtowicz (red.), Rodzina w nurcie współczesnych przemian. Studia interdyscyplinarne, Opole 2010.

Eurostat, Causes of death statistics, 2016, https://ec.europa.eu/eurostat/statistics-explained/index.php/Causes_of_death_statistics\#Developments_between_2006_and_2016 [8/11/2019].

Eurostat, Statistics on young people neither in employment nor in education or training, 2019, https://ec.europa.eu/eurostat/statistics-explained/index.php/Statistics_on_young_ people_neither_in_employment_nor_in_education_or_training dostęp [14.12.2019].

Formella Z., Intervento psico-educativo alla luce della teoria bio-ecologica di Urie Bronfenbrenner, „Teologia i Moralność” 14/1(25)/2019.

Formella Z., Psicologia dell'Intervento educativo, LAS, Roma 2015.

Formella Z., Ricci A., Bambini facili o difficili? Dal carattere all'educazione familiare da o a 6 anni, Anicia, Roma 2013.

Formella Z., Samobójstwo. Refleksja psychopedagogiczna, „Seminare” 20/2004.

Franciszek, Papież, Encyklika „Laudato sì” Ojca świętego Franciszka Poświęcona trosce o wspólny dom, 2015, http://www.vatican.va/content/francesco/pl/encyclicals/documents/papa-francesco_20150524_enciclica-laudato-si.html [30.12.2019].

Franciszek, Papież, Przesłanie papieża Franciszka do uczestników szczytu klimatycznego z 23.09.2019, w: https://www.swietostworzenia.pl/2-aktualne/848-franciszek-douczestnikow-szczytu-klimatycznego-w-nowym-jorku [30.12.2019].

Franklin J.C., Huang X., Bastidas D., Virtual reality suicide: Development of a translational approach for studying suicide causes, „Behaviour Research and Therapy” 120/2019.

Główny Urząd Statystyczny, Atlas demograficzny Polski. Warszawa: Główny Urzq̨d Statystyczny, 2017, https://stat.gov.pl/obszary-tematyczne/inne-opracowania/inne-opracowania-zbiorcze/atlas-demograficzny-polski,28,1.html [8.11.2019].

Goodfellow B., Kolves K., De Leo D., Contemporary Definitions of Suicidial Behavior: A Systematic Literature Review, „Suicide and Life-Threatening Behavior” 49(1)/2019.

Grządziel D., Educare il carattere. Per una pratica educativa teoricamente fondata, LAS, Roma 2014.

Hayes L., Bailey A., Ciarrochi J., W pułapce myśli - Dla nastolatków. Jak skutecznie poradzić sobie z depresją, stresem i lękiem, Gdańskie Wydawnictwo Psychologiczne, Sopot 2019.

Hayes L., Ciarrochi J., Trudny czas dojrzewania. Jak pomóc nastolatkom radzić sobie z emocjami, osiągać cele i budować więzi, stosujq̨c terapię akceptacji i zaangażowania oraz psychologię pozytywnq, Gdańskie Wydawnictwo Psychologiczne, Sopot 2019.

Hołyst B., Samobójstwo - przypadek czy konieczność, Państwowe Wydawnictwo Naukowe, Warszawa 1983.

Hołyst B., Samobójstwo - ucieczka przed światem czy wołanie o pomoc?, w: https://www. national-geographic.pl/aktualnosci/samobojstwo-ucieczka-przed-swiatem-czy-wolanieo-pomoc [30.12.2019].

Hołyst B., Suicydologia, Lexis Nexis, Warszawa 2012. 
Jarosz M., Samobójstwa w czasach kryzysu, w: Suicydologia, t. VII, Wydawnictwo Naukowe PWN, Warszawa 2015.

Kielan A., Olejniczak D., Czynniki ryzyka oraz konsekwencje zachowan samobójczych z uwzględnieniem problematyki samobójstw dzieci i młodzieży, „Dziecko Krzywdzone. Teoria, badania, praktyka”, 17(3)/2018.

Kral J.M., The Idea of Suicide. Contagion, Imitation, and Cultural Diffusion, Routledge, New York 2019.

Makara-Studzińska M., Przyczyny prób samobójczych u młodzieży w wieku 14-18 lat, „Psychiatria” 10(2)/2013.

Maris W. R., Suicidology: A Comprehensive Biopsychosocial Perspective, Guilford Publications, New York 2019.

Mukhametzyanova F.G., Panchenko O.L., Rudsinskaya T. F., Saharov A. A., Psychological factors of suicidal risk among adolescents with speech disorders, „Opcion” 34(86)/2018.

Najwyższa Izba Kontroli, Działalność resocjalizacyjna młodzieżowych ośrodków wychowawczych. Informacja o wynikach kontroli, 2018, LSZ.410.004.00.2017. Nr ewid. 153/2017/P/17/099/LSZ, w: https://www.nik.gov.pl/aktualnosci/nik-o-resocjalizacjiw-mlodziezowych-osrodkach-wychowawczych.html [30.12.2019].

Ostaszewski K., Myśli samobójcze a sytuacja rodzinna oraz problemy inter- i eksternalizacyjne u młodzieży w wieku 14-16 lat, „Dziecko Krzywdzone. Teoria, badania, praktyka” 17(3)/2018.

Portelli C., Papantuono M., Le nuove dipendenze. Riconoscerle, capirle, superarle, San Paolo Edizioni, Cinisello Balsamo 2017.

Pospiszyl I., Patologie społeczne, Wydawnictwo Naukowe PWN, Warszawa 2009.

Rainone A., Tenore K., Bertuzzi A., Cantarano S., Carenti M.L., Cruciani L., De Angelis A., Fabene G., Govetto C., Gregini E., Liso F., Pietracci L., Sabatini P., Sisto M., Spennato A., Tommasi D., Il fenomeno del suicidio: epidemologia e definizioni, „Cognitivismo Clinico” 11(2)/2014.

Rajewska-Rager A., Lepczyńska N., Sibilski P., Czynniki ryzyka samobójstw u dzieci i młodzieży ze spektrum choroby i chorobq afektywnq dwubiegunowq o wczesnym poczq̨tku, „Psychiatria Polska”, 49(3)/2015.

Rathus J.H., Miller A.L., DBT (R) Skills Manual for Adolescents, Guilford Publications, New York 2015.

Ringel E., Gdy życie traci sens. Rozważania o samobójstwie, Wydawnictwo Glob, Szczecin 1987.

Smith N.P., Schuler K., Fadoir N., Marie L., Basu N., Socio-ecological context and the interpersonal theory of suicide: A response to hjelmeland \& knizek, „Death Studies” 3/2019.

Stradomska M., Zachowania suicydalne u dzieci i młodzieży a dobro młodzieży. Ujęcie integralne, „Fides et ratio. Kwartalnik naukowy” 1(37)/2019.

Światowa Organizacja Zdrowia, Polskie Towarzystwo Suicydologiczne, Biuro Rzecznika Praw Dziecka, Ministerstwo Edukacji Narodowe Zapobieganie samobójstwom - poradnik dla nauczycieli i innych pracowników szkoły, Fraszka Edukacyjna, Warszawa 2007.

Wasilewska-Ostrowska K., Profilaktyka zachowań suicydalnych wśród młodzieży, „Dziecko Krzywdzone. Teoria, badania, praktyka” 3(14)/2015.

World Health Organization, Preventing suicide: A global imperative. Executive summary, 2014, https://www.who.int/mental_health/suicide-prevention/exe_summary_english. pdf?ua=1. [8.11.2019]. 
World Health Organization, Suicide data, 2018, https://www.who.int/mental_health/prevention/suicide/suicideprevent/en/ [8.11.2019].

Zelazny J., Melhem N., Porta G., Biernesser C., Keilp J.G., Mann J.J., Oquendo M.A., Stanley B., Brent D. A., Childhood maltreatment, neuropsychological function and suicidal behavior, „Journal of Child Psychology and Psychiatry” 60(10)/2019.

Ziółkowska B., Wycisk J., Autodestruktywność dzieci i młodzieży, Dyfin, Warszawa 2019.

Zwoliński A., Krzywdzone dzieci. Zagrożenia współczesnego dzieciństwa, WAM, Kraków 2012. 
